Економічні науки: збірник наукових праць Луцького національного технічного університету. Серія "Регіональна економіка". Випуск 18 (71). Редкол.: відп. ред. д.е.н., професор Л.Л. Ковальська. Луцьк: ІВВ Луцького НТУ, 2021. 278 с.

the regional labor market: trends, patterns, forecasts]. Lutsk: IVV Lutsk NTU, $220 \mathrm{p}$.

6. Holovne upravlinnya statystyky u Volyns'kiy oblasti: ofitsiynyy veb-sayt [Main Department of Statistics in the Volyn region. Official website]. Retrieved from http://www.lutsk.ukrstat.gov.ua. [in Ukrainian].

7. Economic activity of the population of Ukraine 2013 (2014). Statistical collection. State Statistics Service of Ukraine. Kyiv, 197 p. [in Ukrainian].

8. Economic activity of the population of Ukraine 2014 (2015). Statistical collection. State Statistics Service of Ukraine. Kyiv, 207 p. [in Ukrainian].

9. Labor force of Ukraine 2020 (2021). Statistical collection. State Statistics Service of Ukraine. Kyiv, $190 \mathrm{p}$.

DOI: https://doi.org/10.36910/2707-6296-2021-18(71)-27

УДК 658.14 (477.8): 332.14

Шубалий О.М., д.е.н., професор

Гриник I.С., аспірант кафедри економіки

Луцький національний технічний університет

\title{
ОЦІНКА ФІНАНСОВОГО ЗАБЕЗПЕЧЕННЯ СТАЛОГО РОЗВИТКУ ПІВНІЧНО-ЗАХІДНОГО РЕГІОНУ ЗА РАХУНОК КОШТІВ ЗВЕДЕНИХ МІСЦЕВИХ БЮДЖЕТІВ
}

Мета дослідження полягає в проведенні оцінки фінансового забезпечення сталого розвитку Північно-Західного регіону за рахунок коштів зведених місцевих бюджетів. Проведено порівняльний аналіз доходів та рівня самодостатності зведених місцевих бюджетів Волинської та Рівненської областей; порівняльний аналіз динаміки показника валового регіонального продукту, що припадає в середньому на 1 грн загальних видатків місцевих бюджетів; вивчено зміну питомої ваги статей видатків зведених місцевих бюджетів, а також вивчено динаміку показників фінансової стійкості зведених місцевих бюджетів Північно-Західного регіону.

Ключові слова: місцеві бюджети, фінансове забезпечення, сталий розвиток, зведені доходи та видатки бюджету, Північно-Західний регіон. 
Економічні науки: збірник наукових пращь Луцького національного технічного університету. Серія "Регіональна економіка". Випуск 18 (71). Редкол.: відп. ред. д.е.н., професор Л.Л. Ковальська. Луиьк: ІВВ Луцьького НТУ, 2021. 278 с.

Shubalyi O.M. Hrynyk I.S.

\section{ASSESSMENT OF FINANCIAL SUPPORT FOR SUSTAINABLE DEVELOPMENT OF THE NORTH-WEST REGION AT THE EXPENSE OF CONSOLIDATED LOCAL BUDGETS}

Local budgets in the context of administrative reform are an important tool for influencing the socio-economic development of the regions, in particular, can largely determine the implementation of the 2030 Sustainable Development Goals at the regional level. The purpose of the study is to assess the financial support of sustainable development of the North-West region at the expense of consolidated local budgets.

To a large extent, the success of the 2030 Sustainable Development Goals depends on the state of funding in the economic, social and environmental spheres, as well as the level of socio-economic development of the region as a whole. According to the indicator of the share of own revenues in the total revenues of the consolidated budget during the whole period, Volyn region prevailed over Rivne region, which indicates an even greater opportunity for local budgets to generate own revenues for further financing of the Sustainable Development Goals.

Local authorities in Volyn region provide greater economic return from the redistribution of local budgets (which is manifested in changes in the gross regional product), ie in general have a greater impact on the level of socio-economic development of the region than in Rivne. Although in general the difference between these indicators in these regions is insignificant. Local budgets in the North-West region are already becoming not only social budgets, but are increasingly beginning to play a role in stimulating economic development. However, during the analyzed period there was no increase in funding for the environmental component of sustainable development, ie the cost of environmental measures and restoration of ecosystems, the share of which in total expenditures is less than $1 \%$. That is, the local budgets of the region, which is characterized by a strong natural resource potential, are practically separated from the solution of urgent environmental problems. Local budgets in the region are forced to rely mainly on the growth of tax revenues, the share of which has been constantly increasing - from $78.8 \%$ to $89.8 \%$. However, little use is made of opportunities to raise funds from European funds and international grant projects.

Thus, the generalized assessment showed that local budgets have not become an important source of funding for the implementation of the 2030 Sustainable Development Goals in the North-West region. In general, the inability of local budgets in the region to generate sufficient revenues to finance areas related to the implementation of the 2030 Sustainable Development Goals. Whereas only about $10 \%$ of funds are spent on financing economic activities. The main problem is the very low level of funding (up to $1 \%$ ) from local environmental budgets, ie the environmental component of sustainable development of the North-West region. 
Економічні науки: збірник наукових праць Луцького національного технічного університету. Серія "Регіональна економіка". Випуск 18 (71). Редкол.: відп. ред. д.е.н., професор Л.Л. Ковальська. Луцьк: ІВВ Луцького НТУ, 2021. 278 с.

Therefore, given the region's proximity to the European Union, it is important to significantly expand the sources of revenue for local budgets through grants, international financial assistance, etc., especially to increase funding for the environmental component of sustainable development.

Key words: local budgets, financial support, sustainable development, consolidated budget revenues and expenditures, North-West region.

\section{Шубалый А.М., Грынык И.С. \\ ОЦЕНКА ФИНАНСОВОГО ОБЕСПЕЧЕНИЯ УСТОЙЧИВОГО РАЗВИТИЯ СЕВЕРО-ЗАПАДНОГО РЕГИОНА ЗА СЧЕТ СРЕДСТВ СВОДНЫХ МЕСТНЫХ БЮДЖЕТОВ}

Цель исследования состоит в проведении оценки финансового обеспечения устойчивого развития Северо-Западного региона за счет средств сводных местных бюджетов. Проведен сравнительный анализ доходов и уровня самодостаточности сводных местных бюджетов Волынской и Ровенской областей; сравнительный анализ динамики показателя валового регионального продукта, который приходится в среднем на 1 грн общих расходов местных бюджетов; изучено изменение удельного веса статей расходов сводных местных бюджетов, а также изучена динамика показателей финансовой устойчивости сводных местных бюджетов Северо-Западного региона.

Ключевые слова: местные бюджеты, финансовое обеспечение, устойчивое развитие, сводные доходы и расходы бюджета, Северо-Западный регион.

Постановка проблеми у загальному вигляді і її зв'язок 3 важливими науковими та практичними завданнями. Місцеві бюджети в умовах адміністративної реформи виступають важливим інструментом впливу на соціальноекономічних розвиток регіонів, зокрема значною мірою можуть визначати реалізацію Цілей сталого розвитку 2030. 3 іншого боку зрозуміло, що місцеві бюджети також в переважній більшості не $\epsilon$ самодостатніми, адже не всі регіони країни мають належні передумови для їх наповнення. Особливо це стосується місцевих бюджетів регіонів Західної України, рівень соціальноекономічного розвитку яких є порівняно нижчим, що відповідно визначає й доходну частину місцевих бюджетів. До таких регіонів, зокрема можна віднести й Північно-Західний регіон, 
Економічні науки: збірник наукових праць Луцького національного технічного університету. Серія "Регіональна економіка". Випуск 18 (71). Редкол.: відп. ред. д.е.н., професор Л.Л. Ковальська. Луиьк: ІВВ Луиького НТУ, 2021. 278 с.

який охоплює Волинську та Рівненську області. Зважаючи на викладене, особливого значення набуває проведення оцінки фінансового забезпечення сталого розвитку Північно-Західного регіону за рахунок коштів зведених місцевих бюджетів.

Аналіз останніх досліджень, у яких започатковано вирішення проблеми. Вивченню проблемних питань, що стосуються фінансового забезпечення сталого розвитку на міжнародному, національному та регіональному рівнях присвячено багато наукових праць зарубіжних і вітчизняних вчених [1-4]. В той же час питання оцінки фінансового забезпечення сталого розвитку за рахунок коштів місцевих бюджетів саме Північно-Західного регіону України залишається недостатньо глибоко вивченим i потребує проведення спеціального дослідження.

Цілі статті. Мета дослідження полягає в проведенні оцінки фінансового забезпечення сталого розвитку ПівнічноЗахідного регіону за рахунок коштів зведених місцевих бюджетів. Це передбачає реалізацію ряду завдань, що полягають у проведенні: порівняльного аналізу доходів та рівня самодостатності зведених місцевих бюджетів Волинської та Рівненської областей; порівняльного аналізу динаміки показника валового регіонального продукту, що припадає в середньому на 1 грн загальних видатків місцевих бюджетів; аналізу зміна питомої ваги статей видатків зведених місцевих бюджетів, а також вивченні динаміки показників фінансової стійкості зведених місцевих бюджетів Північно-Західного регіону за 2015-2019 pp.

Виклад основного матеріалу дослідження 3 повним обгрунтуванням отриманих наукових результатів. Цілі сталого розвитку 2030 охоплюють 17 напрямків, які охоплюють економічну, соціальну та екологічну сфери, але досягати їх потрібно комплексно, щоб забезпечити синергетичний ефект покращення середовища існування людини. Значною мірою успішність реалізації цих цілей залежить від стану фінансування за цими сферами і напрямами, а також рівня соціальноекономічного розвитку відповідного регіону загалом. 
Економічні науки: збірник наукових праць Луцького національного технічного університету. Серія "Регіональна економіка". Випуск 18 (71). Редкол.: відп. ред. д.е.н., професор Л.Л. Ковальська. Луцьк: ІВВ Луцького НТУ, 2021. 278 с.

Якщо виділити серед джерел фінансування досягнення Цілей сталого розвитку 2030 кошти зведених місцевих бюджетів, то важливо вивчити в динаміці яким чином вони витрачаються, наскільки місцеві бюджети взагалі здатні впливати на рівень сталого розвитку регіону загалом.

Тому спочатку важливо проаналізувати динаміку суми доходів та рівня самодостатності зведених місцевих бюджетів Волинської та Рівненської областей (рис. 1).

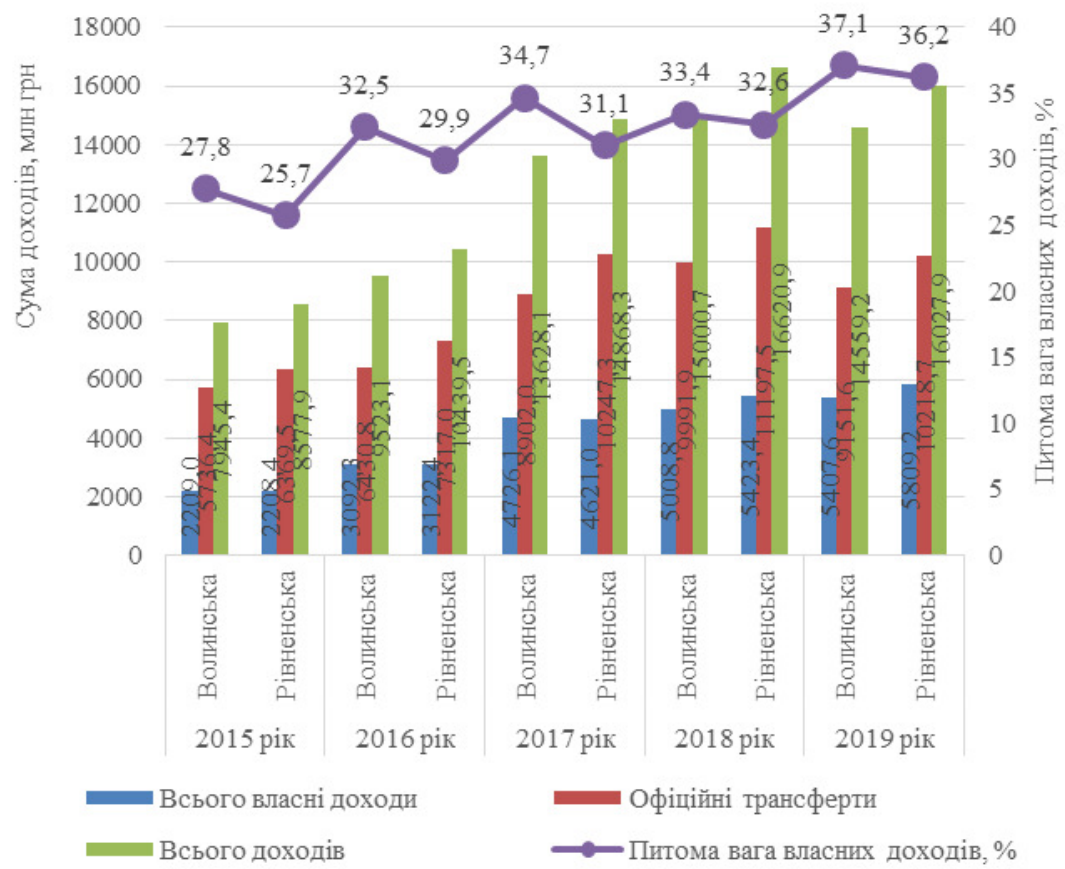

Рис. 1. Порівняльний аналіз доходів та рівня самодостатності зведених місцевих бюджетів Волинської та Рівненської областей за 2015-2019 рр. (складено за: [5-7])

Отже, якщо аналізувати динаміку загальних доходів, то у Рівненській області протягом усього аналізованого періоду вони 
Економічні науки: збірник наукових праць Луцького національного технічного університету. Серія "Регіональна економіка". Випуск 18 (71). Редкол.: відп. ред. д.е.н., професор Л.Л. Ковальська. Луиьк: ІВВ Луиького НТУ, 2021. 278 с.

незначно переважали аналогічний показник Волинської області. При цьому, різниця між цими показниками у 2019 році набула найбільшого значення, але загальні доходи також мали тенденцію до зростання. Разом з тим, аналіз динаміки власних доходів бюджетів цих областей показує, що Волинська область у 2015 році та у 2017 році мала більші власні доходи, ніж Рівненська, незважаючи на переважання загальної суми доходів зведеного бюджету. В інші періоди різниця між цими регіонами за цим показником також була незначною, але вже на користь Рівненської області. Сума офіційних трансфертів як складова доходів місцевих бюджетів протягом аналізованого періоду у 3-4 рази переважала власні доходи цих бюджетів. Про рівень самодостатності місцевих бюджетів свідчить динаміка показника питомої ваги власних доходів у загальних доходах зведеного бюджету. Як бачимо, за цим показникам протягом усього періоду Волинська область переважала Рівненську, що говорить про порівно більшу можливість місцевих бюджетів генерувати власні доходи для подальшого фінансування реалізації Цілей сталого розвитку саме у Волинській області.

На наступному етапі доцільно проаналізувати як загальні видатки місцевих бюджетів Волинської та Рівненської областей вливають на зміну показника валового регіонального продукту за тривалий період часу (рис. 2).

3 рисунка видно, що рівень віддачі в середньому 1 грн видатків місцевих бюджетів Волинської та Рівненської областей 3 позицій забезпечення зростання валового регіонального продукту має тенденцію до зменшення. При цьому, за значенням протягом останніх 2017-2019 рр. цей показник у Волинській області $є$ порівняно вищим, ніж у Рівненській області. Це загалом говорить, що місцеві органи влади у Волинській області забезпечують більшу економічну віддачу (яка проявляється у зміні показника валового регіонального продукту) від перерозподілу коштів місцевих бюджетів, тобто загалом мають більший впливав на рівень соціальноекономічного розвитку регіону, ніж у Рівненській. Хоча загалом 
Економічні науки: збірник наукових праць Луцького національного технічного університету. Серія "Регіональна економіка". Випуск 18 (71). Редкол.: відп. ред. д.е.н., професор Л.Л. Ковальська. Луцьк: ІВВ Луцького НТУ, 2021. 278 с.

різниця між вказаними показниками по цих регіонах $\epsilon$ незначною.

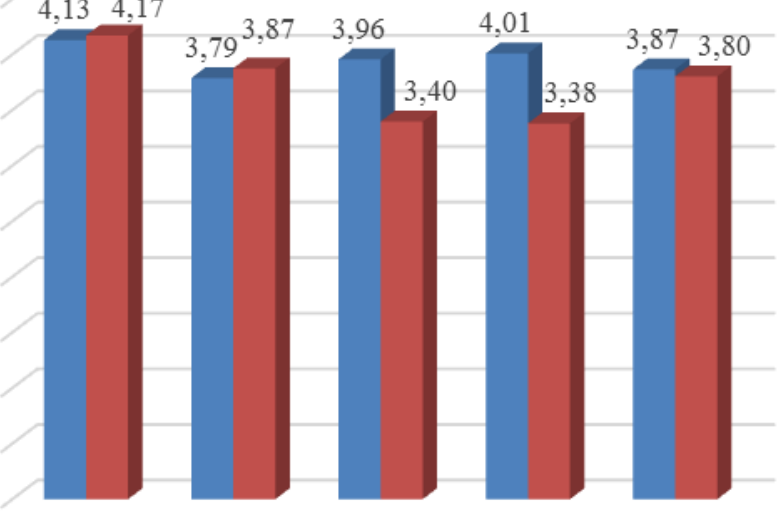

2015 рік 2016 рік 2017 рік 2018 рік 2019 рік

\section{- Волинська область}

Рис. 2. Порівняльний аналіз динаміки показника валового регіонального продукту, що припадає в середньому на 1 грн загальних видатків місцевих бюджетів Волинської та Рівненської областей за 2015-2019 рр. (складено за: [5-7])

Надалі важливо зосередитися на детальнішому вивченні зміни структури основних статей видатків зведених місцевих бюджетів в цілому по Північно-Західного регіону (рис. 3).

3 рисунка видно, що протягом даного періоду найбільшу питому вагу серед видатків зведеного місцевого бюджету займали видатки на освіту, частка яких збільшилася з 32,8\% у 2015 році до 38,8\% у 2019 році. До негативних змін можна віднести зменшення часток фінансування охорони здоров'я (3 $18,3 \%$ до 14,1\%), соціального захисту та соціального забезпечення (з 31,7\% до 23,2\%), культури і мистецтва (з 3,5\% до 2,6\%), натомість зростання частки витрат на державне управління (з 3,1\% до 5,4\%). 
Економічні науки: збірник наукових праць Луцького національного технічного університету. Серія "Регіональна економіка". Випуск 18 (71). Редкол.: відп. ред. д.е.н., професор Л.Л. Ковальська. Луцьк: ІВВ Луцького НТУ, 2021. 278 с.

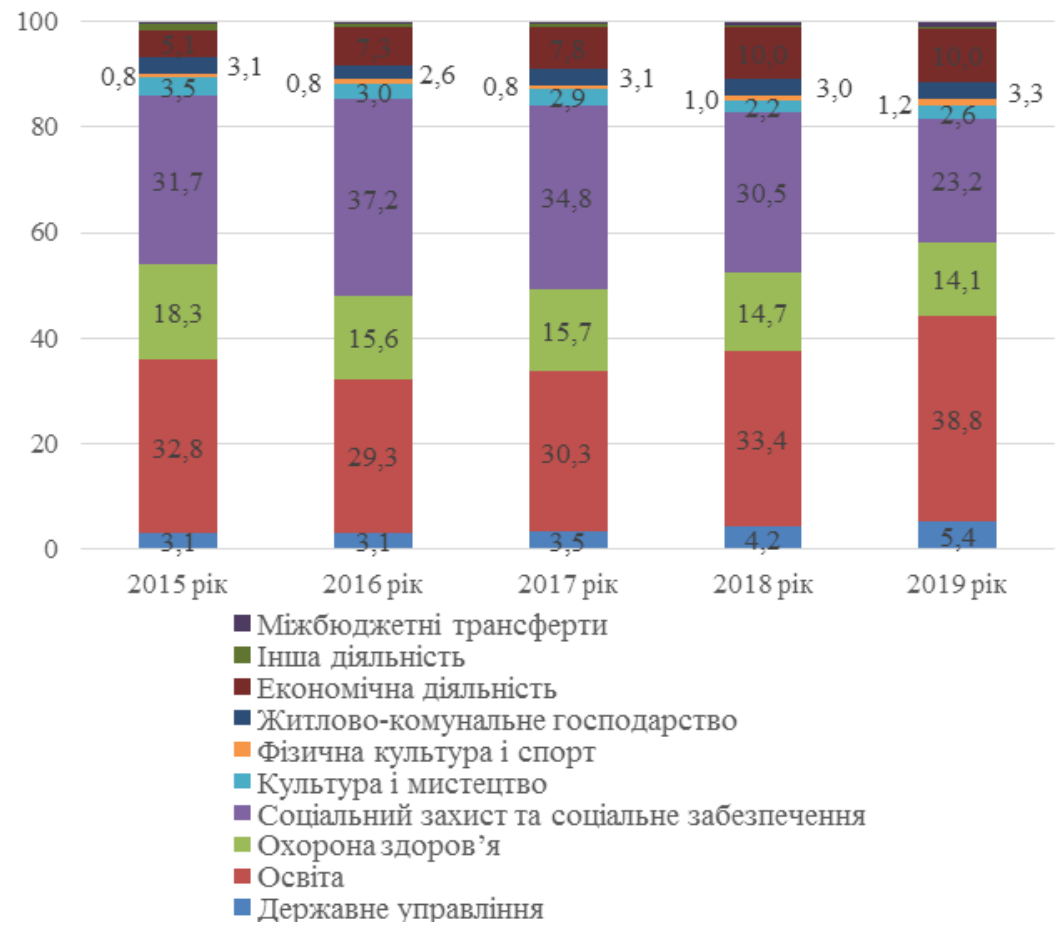

Рис. 3. Зміна питомої ваги статей видатків зведених місцевих бюджетів Північно-Західного регіону за 2015-2019 рр., $\%$ (складено за: [5-7])

Низькими залишалися частки витрат на житловокомунальне господарство (близько 3\%) та фізичну культуру i спорт (близько 1\%). До певних позитивних змін можна віднести зростання у 2 рази частки фінансування економічної діяльності 3 $5,1 \%$ до 10,0\%. Тобто місцеві бюджети Північно-Західного регіону вже стають не лише бюджетами соціального спрямування, але й все більшою мірою починають виконувати функцію стимулювання економічного розвитку. 3 іншого боку, протягом аналізованого періоду не спостерігалося зростання фінансування екологічного компоненти сталого розвитку, тобто 
Економічні науки: збірник наукових праць Луцького національного технічного університету. Серія "Регіональна економіка". Випуск 18 (71). Редкол.: відп. ред. д.е.н., професор Л.Л. Ковальська. Луцьк: ІВВ Луцького НТУ, 2021. 278 с.

витрат на природоохоронні заходи та відновлення екосистем, частка яких у загальних видатках становить менше $1 \%$. Тобто місцеві бюджети даного регіону, який відзначається потужним природно-ресурсним потенціалом, практично відособлюються від вирішення нагальних екологічних проблем.

Надалі важливо проаналізувати динаміку показників фінансової стійкості зведених місцевих бюджетів ПівнічноЗахідного регіону (рис. 4).

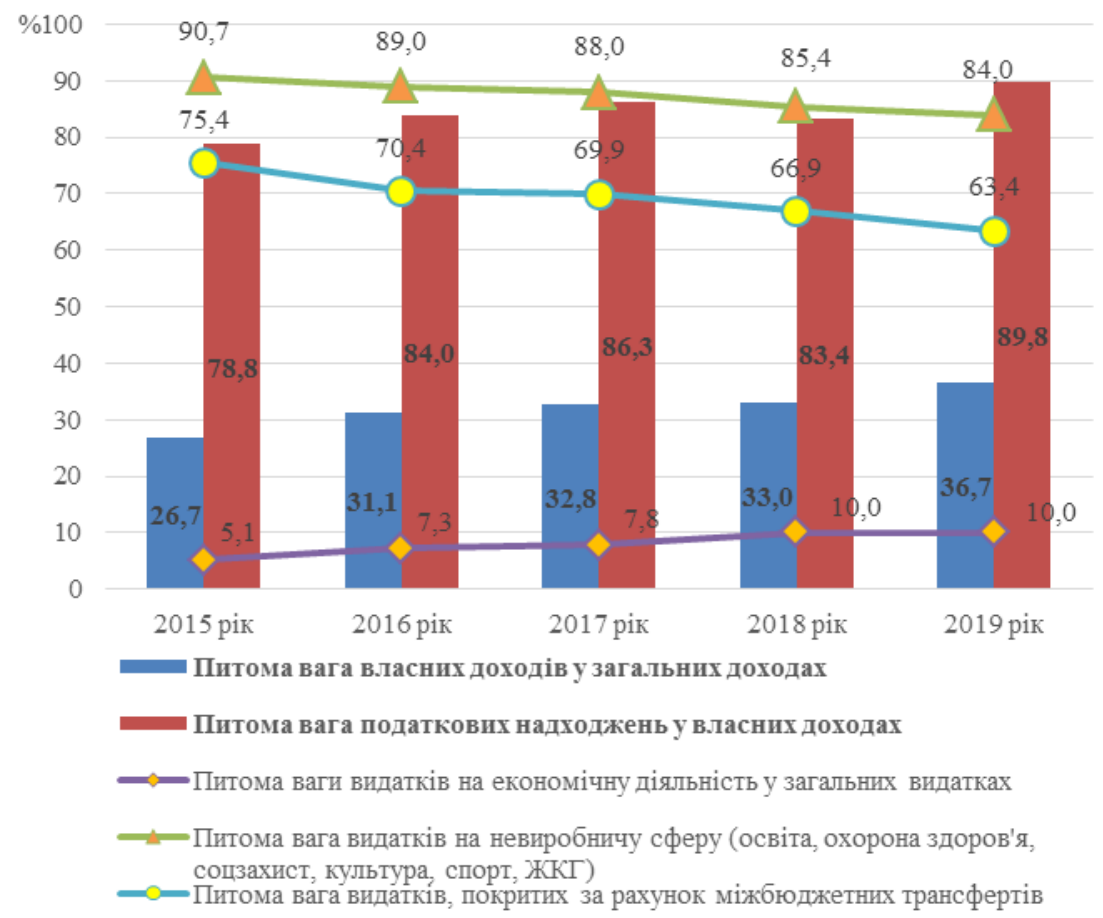

Рис. 4. Динаміка показників фінансової стійкості зведених місцевих бюджетів Північно-Західного регіону за 2015-2019 pp. (побудовано за даними [5-7])

До позитивних моментів можна віднести зростання питомої ваги власних доходів місцевих бюджетів в цілому 
Економічні науки: збірник наукових праць Луцького національного технічного університету. Серія "Регіональна економіка". Випуск 18 (71). Редкол.: відп. ред. д.е.н., професор Л.Л. Ковальська. Луиьк: ІВВ Луиького НТУ, 2021. 278 с.

Північно-Західного регіону за аналізований період з 26,7\% $36,7 \%$, але це тільки третина від освоєних коштів, що говорить про дотаційний характер місцевих бюджетів. Місцеві бюджети регіону змушені переважно надіятися на зростання податкових надходжень, частка яких постійно збільшувалася - 3 78,8\% до $89,8 \%$. 3 іншого боку, не використовуються можливості залучення коштів Європейських фондів та міжнародних грантових проектів. До позитивних змін можна віднести збільшення частки видатків на економічну діяльність до $10,0 \%$. Разом $з$ тим, прослідковується більша спрямованість видатків на невиробничу сферу, але їх частка поступово знижувалася протягом досліджуваного періоду 3 90,7\% до 84,0\%. Також безперечним позитивним моментом $\epsilon$ зменшення частки видатків, покритих за рахунок міжбюджетних трансфертів (3 $75,4 \%$ до 63,4\%), хоча вона залишається надто великою.

Висновки. Отже, проведена узагальнена оцінка засвідчила, що місцеві бюджети не стали важливим джерелом фінансування процесу реалізації Цілей сталого розвитку 2030 у Північно-Західному регіоні. Загалом виявлено нездатність місцевих бюджетів даного регіону генерувати достатню суму доходів для фінансування напрямів, пов'язаних 3 реалізацією Цілей сталого розвитку 2030. Адже вони на 2/3 залишаються дотаційними і спрямованими переважно на вирішення поточних соціальних питань, тобто фінансування соціальної компоненти сталого розвитку. Тоді як на фінансування економічної діяльності витрачається тільки близько $10 \%$ коштів. Основною проблемою є дуже низький рівень фінансування (до 1\%) за рахунок коштів місцевих бюджетів природоохоронної діяльності, тобто екологічної компоненти сталого розвитку Північно-Західного регіону.

Тому надалі, враховуючи близькість даного регіону до Європейського Союзу, важливо суттєво розширити джерела наповнення доходної частини місцевих бюджетів за рахунок грантових коштів, міжнародної фінансової допомоги тощо, особливо 3 метою підвищення фінансування екологічної компоненти сталого розвитку. 
Економічні науки: збірник наукових праць Луцького національного технічного університету. Серія "Регіональна економіка". Випуск 18 (71). Редкол.: відп. ред. д.е.н., професор Л.Л. Ковальська. Луиьк: ІВВ Луиького НТУ, 2021. 278 с.

\section{Список бібліографічного опису}

1. Вахович I.М., Ропотан І.В. (2013). Фінансові джерела забезпечення сталого розвитку регіону. Вісник Університету банківської справи Національного банку Украӥни, 1 (16), 26-29.

2. Zioło Magdalena. Finanse zrównoważone. Rozwój, ryzyko, rynek. Wydawnictwo PWE, Warszawa, 2020.

3. UNEP. (2016). Fiscal policies and the SDGs. Green economy. Policy brief. https://greenfiscalpolicy.org/policy_briefs/fiscal-policies-and-the-sdgs-uneppolicy-brief/

4. Шубалий О.М., Гриник I.С. (2021). Фінансове забезпечення сталого розвитку регіону. Evropský časopis ekonomiky a management, Vol. 7, Issue 1. 7180.

5. Статистичні збірники Міністерства фінансів України «Бюджет України»: офіційний веб-сайт Міністерства фінансів України: URL: https://www.mof.gov.ua/uk/statistichnij-zbirnik

6. Головне управління статистики у Волинській області : офіційний веб-сайт: URL: http://www.lutsk.ukrstat.gov.ua.

7. Головне управління статистики у Рівненській області : офіційний веб-сайт: URL: http://www.gusrv.gov.ua.

\section{References}

1. Vakhovych, I.M., Ropotan, I.V. (2013). Finansovi dzherela zabezpechennia staloho rozvytku rehionu [Financial sources of sustainable development of the region]. Visnyk Universytetu bankivskoi spravy Natsionalnoho banku Ukrainy. [Bulletin of the university of banking of the National bank of Ukraine], 1 (16), 26-29. [in Ukrainian].

2. Zioło Magdalena (2020). Finanse zrównoważone. Rozwój, ryzyko, rynek. Wydawnictwo PWE, Warszawa [Sustainable finance. Development, risk, market]. PWE Publishing House, Warsaw. [in Polish].

3. UNEP. (2016). Fiscal policies and the SDGs. Green economy. Policy brief. https://greenfiscalpolicy.org/policy_briefs/fiscal-policies-and-the-sdgs-uneppolicy-brief/

4. Shubalyi O.M, Hrynyk I.S. (2021). Finansove zabezpechennya staloho rozvytku rehionu. [Financial support for sustainable development of the region]. Evropský časopis ekonomiky a management, Vol. 7, Issue 1. 71-80. [in Ukrainian].

5. Statystychni zbirnyky Ministerstva finansiv Ukrayiny «Byudzhet Ukrayiny»: ofitsiynyy veb-sayt Ministerstva finansiv Ukrayiny [Statistical collections of the Ministry of Finance of Ukraine "Budget of Ukraine": Official website of the Ministry of Finance of Ukraine] Retrieved from: https://www.mof.gov.ua/uk/statistichnij-zbirnik [in Ukrainian].

6. Holovne upravlinnya statystyky u Volyns'kiy oblasti: ofitsiynyy veb-sayt [Main Department of Statistics in the Volyn region. Official website]. Retrieved from: http://www.lutsk.ukrstat.gov.ua [in Ukrainian]. 
Економічні науки: збірник наукових праць Луцького національного технічного університету. Серія "Регіональна економіка". Випуск 18 (71). Редкол.: відп. ред. д.е.н., професор Л.Л. Ковальська. Луцьк: ІВВ Луцького НТУ, 2021. 278 с.

7. Holovne upravlinnya statystyky u Rivnens'kiy oblasti: ofitsiynyy veb-sayt [Main Department of Statistics in Rivne Region: official website]. Retrieved from: http://www.gusrv.gov.ua [in Ukrainian].

DOI: https://doi.org/10.36910/2707-6296-2021-18(71)-28 